\title{
Lyophilized and microencapsulated extracts of grape pomace from winemaking industry to prevent lipid oxidation in chicken pâté
}

\author{
Extratos liofilizados e microencapsulados de bagaço de uva \\ oriundo de vinícolas para prevenir a oxidação lipídica em patê \\ de frango
}

\begin{abstract}
Solange Teresinha Carpes ${ }^{1 *}$ (1), Daiane Pereira ${ }^{1}$, Cristiane de Moura$^{1}$, Amália Soares dos Reis $^{1}$, Leticia Dangui da Silva ${ }^{1}$, Tatiane Luiza Cadorin Oldoni ${ }^{1}$, Jacqueline Florio Almeida ${ }^{2}$, Manuel Vicente Salvador Plata-Oviedo

\author{
${ }^{1}$ Universidade Tecnológica Federal do Paraná (UTFPR), Programa de Pós-graduação em Tecnologia de Processos \\ Químicos e Bioquímicos (PPGTP), Pato Branco/PR - Brasil \\ ${ }^{2}$ Universidade Tecnológica Federal do Paraná (UTFPR), Programa de Pós-graduação em Tecnologia de Alimentos \\ (PPTA), Campo Mourão/PR - Brasil
}

*Corresponding Author: Solange Teresinha Carpes, Universidade Tecnológica Federal do Paraná (UTFPR), Programa de Pós-graduação em Tecnologia de Processos Químicos e Bioquímicos (PPGTP), Rodovia do Conhecimento, km 01, CEP: 85503-390, Pato Branco/PR - Brasil, e-mail: carpes@utfpr.edu.br

Cite as: Carpes, S. T., Pereira, D., Moura, C., Reis, A. S., Silva, L. D., Oldoni, T. L. C., Almeida, J. F., \& PlataOviedo, M. V. S. (2020). Lyophilized and microencapsulated extracts of grape pomace from winemaking industry to prevent lipid oxidation in chicken pâté. Brazilian Journal of Food Technology, 23, e2019112. https://doi.org/10.1590/1981-6723.11219

\begin{abstract}
The aim of this study was to characterize spray-dried and lyophilized powders made from winery by-products and to evaluate their effect on the oxidative stability of chicken pâté. Phenolic profile, antioxidant activity, and microencapsulation efficiency were evaluated in the extracts. Two pâté formulations containing grape pomace lyophilized (GPWL) and grape pomace microencapsulated (GPWM) were produced. In addition, a sodium erythorbate and a control batch were used to compare the effects. The pâtés were evaluated by thiobarbituric acid reactive substances (TBARS) assay during refrigerated storage $\left(4^{\circ} \mathrm{C} / 42\right.$ days). Although the microencapsulation efficiency was $90.03 \%$, the GPWL was statistically more effective in the lipid oxidation inhibition in chicken pâte than GPWM. However, the addition of both natural antioxidants in chicken pâté resulted in lower TBARS values than pâté treated with synthetic antioxidant due to the presence of gallic acid, caffeic acid, vanillic acid, ferulic acid, coumaric acid and trans-resveratrol with high antioxidant activity. Thus, the bioactive compounds with antioxidant activity detected in the GPWL and GPWM opened possibilities for use as a potential ingredient in chicken pâté and other meat products.
\end{abstract}

Keywords: Meat products; Vitis labrusca L.; Oxidative stability; Spray drying; Antioxidants; Agro-industrial waste. 


\section{Resumo}

O objetivo deste estudo foi caracterizar os extratos liofilizados e microencapsulados obtidos a partir de resíduos de vinícola e avaliar os efeitos de sua adição na estabilidade oxidativa do patê de frango. O perfil fenólico, a atividade antioxidante e a eficiência da microencapsulação foram avaliados nesses extratos. Duas formulações de patê contendo bagaço de uva liofilizado (GPWL) e bagaço de uva microencapsulado (GPWM) foram produzidas. Além disso, uma formulação com eritorbato de sódio e uma formulação controle foram usadas para comparar os efeitos. Os patês foram avaliados pelo método de substâncias reativas ao ácido tiobarbitúrico (TBARS) durante o armazenamento refrigerado $\left(4^{\circ} \mathrm{C} / 42\right.$ dias). Apesar de a eficiência de microencapsulação ter sido de $90,03 \%$, o GPWL foi estatisticamente mais efetivo na inibição da oxidação lipídica no patê de frango do que o GPWM. No entanto, a adição de ambos os antioxidantes naturais no patê de frango resultou em valores mais baixos de TBARS do que o patê tratado com antioxidante sintético por causa da presença de ácido gálico, ácido cafeico, ácido vanílico, ácido ferúlico, ácido cumárico e trans-resveratrol com alta atividade antioxidante. Dessa forma, a presença dos compostos bioativos com atividade antioxidante detectados no GPWL e no GPWM abre possibilidades para uso como ingrediente potencial no patê de frango e demais produtos cárneos.

Palavras-chave: Produtos cárneos; Vitis labrusca L.; Estabilidade oxidativa; Secagem por pulverização; Antioxidantes; Resíduo agroindustrial.

\section{Introduction}

Natural products have been valuable sources for the development of new active principles, allowing the discovery of biomolecules with potential use in many areas of science (Falowo et al., 2014). Successful aging and disease prevention including cancer and cardiac problems have been attributed to the ingestion of polyphenol-rich foods (Zhang et al., 2015).

Seeds, skin, stems and grape pulp remains form by-products of the grape wine processing, which are rich in phenolic compounds as anthocyanins, trans-resveratrol, dyes and other compounds with biological activities namely antioxidant, antibacterial, anti-inflammatory, and cytotoxic activities (Peixoto et al., 2018). If the generation of large-scale by-products is discarded inappropriately can have a negative impact on the environment. However, if well used, they can generate economic and environmental gains. On the other hand, the use of bioactive compounds in the food industry has some limitations due to the bitter taste of major phenolic compounds and according to Soares et al. (2013), the bitterness of polyphenols increases with molecular weight.

Thus, the use of encapsulated polyphenols rather than free compounds can effectively alleviate those deficiencies. In fact, it has been well-known that the main purpose of encapsulation is to protect the bioactive material from adverse environmental conditions, such as undesirable effects of light, moisture and oxygen (He \& Hwang, 2016; Çam et al., 2014; Jyothi et al., 2010). Furthermore, powders provide a controlled release of the bioactive compound in the final product, contributing to an increase in the shelf life of food products (Jyothi et al., 2010).

Bioactive compounds extracted from food by-products should have technological advantages for the food industry such as inhibit lipid oxidation and present antimicrobial activity. In fact, lipid oxidation is one of the most important parameters that influence the quality and acceptance of chicken meat (Sampaio et al., 2012) and is a complex process in which unsaturated fatty acids from meat products can react with molecular oxygen and produce malonaldehyde, a co-product of hydroperoxides decomposition formed during the oxidation process (Kim et al., 2013).

Synthetic additives are used routinely in food technology against lipid oxidation. However, due to their potential disease risk (Shahidi \& Zhong, 2010), the consumer has preferred natural foods, such as herbs, plants (Falowo et al., 2014), fruits (Kim et al., 2013), apicultural products (Reis et al., 2017) and agro-industrial waste (Pateiro et al., 2015; Melo et al., 2011) which have antioxidant and antimicrobial properties. Chicken 
pâté has a short shelf life which makes its commercialization more difficult. In fact, previous studies have been reported that the natural additives added in the process can improve the quality of meat products during the storage (Almeida et al., 2017; Sampaio et al., 2012).

Thus, the aim of this study was to evaluate the influences of the phenolic composition of lyophilized and microencapsulated extracts from winery by-products on chicken pâté to prevent lipid oxidation during processing and storage.

\section{Material and methods}

\subsection{Chemicals}

Gallic acid, ABTS (2.2'-azino-bis (3-ethylbenzothiazoline-6-sulphonic acid)), TPTZ (2.4.6-Tris(2pyridyl)-s-triazine), Folin-Ciocalteu phenol reagents, gallic acid, vanillic acid, caffeic acid, coumaric acid, ferulic acid, and trans-resveratrol were obtained from Sigma-Aldrich (Sternheim, Germany). Ethyl alcohol and methanol were purchased from Vetec (Brazil). All reagents used were of analytical grade. Maltodextrin 10 DE was obtained from Cargil Foods (São Paulo, Brazil).

\subsection{Samples}

The grape pomace of varieties of Vitis labrusca L. Bordeaux was supplied by a winery from Mariópolis, Paraná, Southwest region of Brazil and was collected in Summer 2017. Grape pomace is the solid remains of grapes after the juice has been extracted and was composed of stem, seed, skin, and pulp. Grape pomace was dried in a stove at $35 \pm 3{ }^{\circ} \mathrm{C}$ for two days, minced in an analytical mill and stored at $-12{ }^{\circ} \mathrm{C}$.

\subsection{Preparation of the ethanolic extract}

We extracted $100 \mathrm{~g}$ of grape pomace (dry basis) with $1 \mathrm{~L}$ of ethanol solution $(80 \%$, v/v) in a shaker (SL 222, Brazil) at $40^{\circ} \mathrm{C}$ for $60 \mathrm{~min}$ at a 200-rpm stirring rate. After filtrating, the supernatant was evaporated in a rotary evaporator (Fisatom 802, Brazil) (vacuum pressure of $600 \mathrm{~mm} \mathrm{Hg}$ and $40{ }^{\circ} \mathrm{C}$ ) until completely dried, or up until $20 \%$ of the liquid was soluble, and then they were lyophilized (Liotop L101, Brazil), which could be used after in the dispersion preparation. The lyophilized ethanolic extract was named as GPWL: grape pomace wine lyophilized.

\subsection{Preparation of dispersion and microparticles}

We used $50 \mathrm{~mL}$ of cold water to dissolve $50 \mathrm{~g}$ of maltodextrin, and then $50 \mathrm{~mL}$ of water at $90{ }^{\circ} \mathrm{C}$ was added under stirring for $5 \mathrm{~min}$ in Ultra-Turrax (MA-102, Brazil) at $894 \times \mathrm{g}$. The grape co-product extract (100 g, 20\% soluble solids) was added under stirring for $3 \mathrm{~min}$. The spray dryer (Labmaq MSD 1.0, Brazil) was used with a flow regime in counterflow $(1 \mathrm{~L} / \mathrm{h})$. The drying chamber had a diameter of $500 \mathrm{~mm}$ and a height of $1800 \mathrm{~mm}$. The dispersion containing the extract and maltodextrin was fed to the spray dryer through a feed system (feed flow $0.60 \mathrm{~L} / \mathrm{h}$ ) consisting of a peristaltic pump, a two-fluid atomizer (with an inlet orifice diameter of $1.0 \mathrm{~mm}$ ) and an air compressor $(50 \mathrm{~L} / \mathrm{min})$. The drying air flow rate was maintained constant at $3.6 \mathrm{~m}^{3} / \mathrm{min}$. The inlet and outlet air temperatures were $150{ }^{\circ} \mathrm{C}$ and $100{ }^{\circ} \mathrm{C}$, respectively. The microencapsulated extract was named as GPWM: Grape pomace wine microencapsulated. 


\subsection{Microencapsulation Efficiency (ME), Scanning Electron Microscopy (SEM) and Water activity (Aw)}

Microencapsulation efficiency analysis was determined by Farrag et al. (2018) and was considered the ratio of encapsulated phenolic content to total phenolic compounds of microparticles (TPC). Thus, the encapsulated phenolic content was determined by the difference between TPC and surface phenolic content (SPC). The microencapsulation process efficiency was determined by Equation 1. The SPC was extracted with $0.2 \mathrm{~g}$ of powder and $2.0 \mathrm{~mL}$ of ethanol, mixed in a tube stirrer (Phoenix, Brazil) and centrifuged for 2 $\min$ at $1789 \times \mathrm{g}$ (Novatecnica NT 825, Brazil). While the TPC was performed with $0.5 \mathrm{~g}$ of powder and 20 $\mathrm{mL}$ of methanol $80 \%$ and acidified with $1 \mathrm{~mL}$ of $\mathrm{HCl}$. After the centrifugation, $0.1 \mathrm{~mL}$ of each supernatant was transferred for an individual glass tube to determine the total phenolic compounds by the Folin Ciocalteu method according to Singleton et al. (1999).

$M E(\%)=\left(\frac{T P C-S P C}{T P C}\right) * 100$

For scanning electron microscopy (SEM), the microencapsulated samples were fixed directly on door-metallic specimens (stubs) of $12 \mathrm{~mm}$ diameter and the particle morphology of the microparticles was observed by SEM (TM-3000 Hitachi Tabletop Microscope, Japan). The images were captured by Hitachi Tabletop software Shadow 1 with a voltage acceleration of $5 \mathrm{kV}$, the flow of $1750 \mathrm{~mA}$ and observed with 4000 and $5000 \mathrm{X}$ magnifications.

The Aw test of the microparticles was performed at $25^{\circ} \mathrm{C}$ on analyzer Aw (AquaLab, Decagon Devices, Pullman, WA).

\subsection{Total Phenolic Compounds (TPC) and Total Anthocyanin Content (TAC)}

The TPC was determined by the Folin-Ciocalteu method, as described by Singleton et al. (1999), using gallic acid as a reference pattern. We individually added $0.5 \mathrm{~mL}$ of each sample to $3.0 \mathrm{~mL}$ of distilled water and $0.25 \mathrm{~mL}$ of Folin-Ciocalteu reagent. The absorbance was measured in a spectrophotometer at $765 \mathrm{~nm}$ and the results were expressed in GAE: Gallic Acid Equivalent (mg GAE/g grape pomace dry weight).

The TAC was determined using the pH-differential method, as described by Lee et al. (2005), with some modifications, using two buffer systems: potassium chloride buffer $(0.025 \mathrm{M}, \mathrm{pH} 1.0)$ and sodium acetate buffer (0.4 M, pH 4.5). One milliliter of the samples was mixed with $9 \mathrm{~mL}$ of the $\mathrm{pH}$ buffer solution, and the absorbance was measured at $520 \mathrm{~nm}$ and $700 \mathrm{~nm}$ on a spectrophotometer (Femto UV 2000, Brazil). The anthocyanin content was expressed as mg cyanidin-3-glucoside equivalents/g grape pomace dry weight (Equation 2):

$\operatorname{TAC}\left(\frac{m g}{L}\right)=\frac{A \times M_{w} \times D F \times 1000}{\varepsilon \times 1}$

where, $A=\left(A_{520}-A_{700}\right)_{p H=1.0}-\left(A_{520}-A_{700}\right)_{p H=4.5} ; \quad M_{w}=$ molecular weight $(\mathrm{g} / \mathrm{mol}) ; \quad D F=$ dilution factor; $\varepsilon=$ extinction coefficient; 1 = path length $(1 \mathrm{~cm})$; extinction coefficient $\varepsilon=28,000 \mathrm{~L} / \mathrm{mol} . \mathrm{cm}$, and molecular weight $=449.2 \mathrm{~g} / \mathrm{mol}$. All measurements were carried out in triplicate.

\subsection{Ferric Reducing Antioxidant Power (FRAP) and Scavenging activity of ABTS*+}

The FRAP was determined by Kukic et al. (2008). The FRAP reagent was obtained mixing $25 \mathrm{~mL}$ of acetate buffer $0.3 \mathrm{M}, 2.5 \mathrm{~mL}$ of $10 \mathrm{mM}$ TPTZ ((2.4.6-Tris(2-pyridyl)-s-triazine), and $2.5 \mathrm{~mL}$ of an aqueous solution of $20 \mathrm{mM}$ ferric chloride. A standard curve was prepared using $\mathrm{FeSO}_{4} .7 \mathrm{H}_{2} \mathrm{O}\left(3.6 \times 10^{-3}\right.$ to $\left.3.6 \times 10^{-2} \mu \mathrm{mol}\right)$. We added $100 \mu \mathrm{L}$ of GPWL and GPWM separately to $3 \mathrm{~mL}$ of freshly prepared FRAP reagent. The reaction mixture was incubated for $30 \mathrm{~min}$ in a water bath at $37^{\circ} \mathrm{C}$, and the absorbance of the samples was measured 
at $595 \mathrm{~nm}$ on a spectrophotometer (Femto UV 2000, Brazil). FRAP values were expressed as $\mu \mathrm{mol} \mathrm{Fe} \mathrm{F}^{2+} / \mathrm{g}$ of the sample. All measurements were carried out in triplicate.

The ABTS method was performed as described by Arnao et al. (2001) and Re et al. (1999) in the GPWL and GPWM. The stock solutions included $7.4 \mathrm{mM} \mathrm{ABTS}^{\circ+}$ and $2.6 \mathrm{mM}$ potassium persulfate. The solution

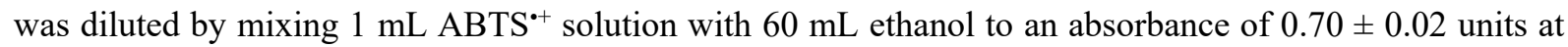
$734 \mathrm{~nm}$ on a spectrophotometer (Femto UV 2000, Brazil). Antioxidant activity was expressed in $\mu \mathrm{mol} / \mathrm{g}$ of TEAC (Trolox-equivalent antioxidant capacity). The assays were carried out in triplicate.

\subsection{Phenolic compound profile by HPLC-DAD analysis}

The GPWL and GPWM extract were analyzed at $0.6 \mathrm{~g} / \mathrm{mL}$ and $0.25 \mathrm{~g} / \mathrm{mL}$, respectively. The chromatographic fingerprinting was carried out on an HPLC system equipped with a photodiode array (PDA) detector (Varian, 920-LC, US) and Galaxie software. The separation was performed at $31{ }^{\circ} \mathrm{C}$ using a Varian C-18 RP $(250 \mathrm{~mm} \times 4.6 \mathrm{~mm}, 5 \mu \mathrm{m})$ column. The injection volume was $10 \mu \mathrm{L}$ and the detection was carried out between 240 and $400 \mathrm{~nm}$. The separation was obtained using ultrapure water (solvent A) and methanol (solvent B) as the mobile phase at a constant flow rate of $1.0 \mathrm{~mL} / \mathrm{min}$. The gradient $(\mathrm{v} / \mathrm{v})$ was obtained, keeping $95 \%$ of solvent A for $5 \mathrm{~min}$, then decreasing it to $50 \%$ in $30 \mathrm{~min}$, then to $10 \%$ in $55 \mathrm{~min}$, remaining at this concentration for another $5 \mathrm{~min}$ and then returning to the initial condition, to $95 \%$ for $10 \mathrm{~min}$. The identification was performed by comparing retention times and absorption in ultraviolet, and quantification was carried out by external standardization. The instrumental limits of detection and quantification were $0.34,2.72,0.11,0.08,0.36,0.16 \mathrm{mg} / \mathrm{mL}$ for gallic acid, vanillic acid, caffeic acid, coumaric acid, ferulic acid, and trans-resveratrol, respectively. The experiment was performed in triplicate and the content of phenolic compounds were expressed for each compound in $\mathrm{mg} / 100 \mathrm{~g}$ of the sample.

\subsection{Pâté chicken elaboration and lipid oxidation evaluation}

The GPWL and GPWM were applied in chicken pâté to evaluate the effect of inhibition of lipid oxidation of the product. The pâté formulation used chicken meat (6.22 kg), chicken skin $(1.53 \mathrm{~kg})$, ice water $(1 \mathrm{~kg})$, salt $(50 \mathrm{~g})$, sodium polyphosphate $(20 \mathrm{~g})$ and carmine $(3 \mathrm{~g})$. This basic dough was divided into four lots. The first no additional ingredients were included and named as the control (T1). The second lot was added sodium erythorbate (SE) $(0.3 \mathrm{mg} / \mathrm{g})$ and named as a positive control (T2). The third lot received GPWL ( $3 \mathrm{mg} / \mathrm{g}$ ) (T3), and the fourth lot received the GPWM (3 mg/g) (T4). Separately, the pâté lots were stored in sterile glasses, autoclaved and submitted to a baking process in a water bath at $80^{\circ} \mathrm{C}$ for $30 \mathrm{~min}$ so that the inner temperature reaches $72^{\circ} \mathrm{C}$. After baking, the glass jars containing the pâtés were cooled with water and ice and kept at $4{ }^{\circ} \mathrm{C}$ to evaluate the oxidative stability of the pâtés.

The lipid oxidation was determined at times $0,7,14,21,28,35$ and 42 days by thiobarbituric acid reactive substances (TBARS) method. Tetramethoxypropane (TMP) was used as standard reference (Almeida et al., 2017) and the TBARS levels were expressed as mg of malonaldehyde/kg of the sample. The lipid oxidation was assessed in triplicate.

\subsection{Statistical analysis}

Analysis of variance (ANOVA) was performed to analyze the data, and the means were compared by Tukey's test for TBARS values and $t$-test for phenolic compounds profile, using the Statistica 8.0 software (StatSoft, USA). The results were considered statistically significant when $p<0.05$. 


\section{Results and discussion}

\subsection{Characterization of microparticles}

GPWM showed a spherical shape of various sizes with a smooth surface in the microparticles. According to Reis et al. (2017), these are the characteristic of the microparticles produced in a spray dryer. The sizes of the particles obtained ranged from 3.36 to $8.57 \mu \mathrm{m}$. In fact, according to Favaro-Trindade et al. (2008) and Madene et al. (2006), the encapsulation by the spray drying process generates powders with particles in the range of 5 to $150 \mu \mathrm{m}$. Mostly the outer surfaces of the particles showed no visible cracks, which is positive, since this characteristic is less permeable to external gases, increasing the protection of the active material. In this study, a slight adhesion of smaller particles to the surface of the largest particles was observed (Figure 1). In fact, higher temperatures contribute to the rapid drying of droplets which leads to the formation of smaller droplets, favoring the formation of smoother surfaces. According to Carneiro et al. (2013), Borrmann et al. (2013), and Tonon et al. (2010) the smooth surface of the microparticles are related to the drying temperature; higher temperatures cause water evaporation and quickly lead to the formation of a smoother crust. Additionally, the particle diameter of the spray dryer material employed depends on the atomization method, the properties of the wall material, the concentration and viscosity of the raw material, and the drying conditions (Fernandes et al., 2014). 

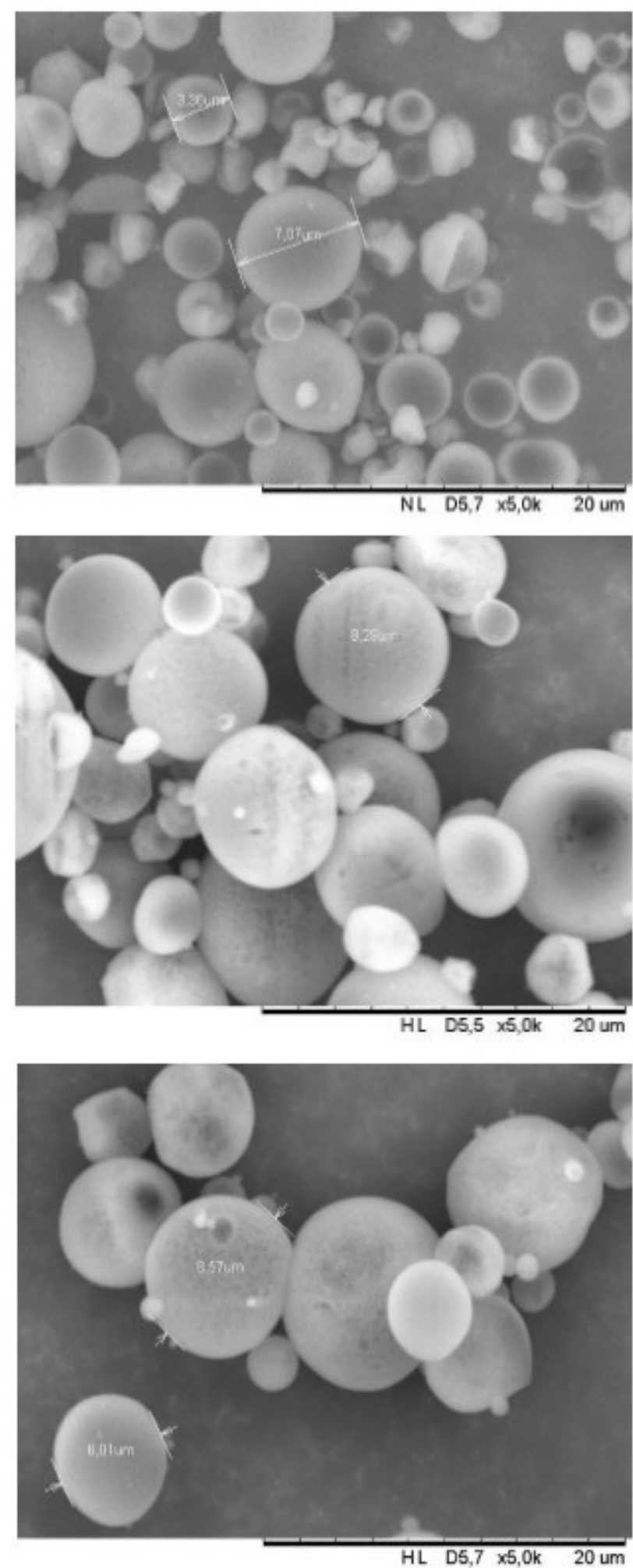

Figure 1. Micrographs by scanning electron microscopy (SEM) of GPWM.

$\mathrm{A}_{\mathrm{w}}$ of GPWL and GPWM extracts were of 0.55 and 0.40 respectively (Table 1). The mean $\mathrm{a}_{\mathrm{w}}$ founded in GPWM is characteristic of dehydrated foods and recommended for good storage stability. According to Bajaj et al. (2015), similar inlet temperature, feed rate, atomizer speed and outlet temperature maintained during spray drying, are responsible for the $\mathrm{a}_{\mathrm{w}}$ of the extracts (Table 1). 
The ME defines the quantity of substance retained within the microspheres and depends uponthe affinity between the wall material and the microencapsulated substance, among other factors. In this study, the use of the maltodextrin as encapsulating material and the drying air temperature $\left(150^{\circ} \mathrm{C}\right)$ was appropriated to achieve high ME value (90.03\%) (Table 1). On the other hand, according to Jyothi et al. (2010), high ME may also be related to other different factors, including the rapid solidification of the microparticles, polymers of low solubility in an organic solvent and high solubility of polymers in water. Another important factor is the interaction between the bioactive compounds of winery by-products and the polymer encapsulating agent, which is generally hydrophobic (Nori et al., 2011).

Table 1. Microencapsulation efficiency, $\mathrm{a}_{\mathrm{w}}$, TPC, TAC, antioxidant activity of GPWL and GPWM extracts.

\begin{tabular}{|c|c|c|c|c|c|c|}
\hline Samples & $\begin{array}{c}\text { Microencaps } \\
\text { ulation } \\
\text { efficiency }(\%)\end{array}$ & $\mathbf{a}_{\mathbf{w}}$ & $\begin{array}{l}\text { TPC (mg } \\
\text { GAE/g) }\end{array}$ & $\begin{array}{c}\text { TAC (mg } \\
\text { cyanidin-3- } \\
\text { glucoside /g) }\end{array}$ & $\begin{array}{c}\text { ABTS }(\mu \mathrm{mol} \\
\text { TEAC/g) }\end{array}$ & $\begin{array}{c}\text { FRAP }(\mu \mathrm{mol} \\
\left.\qquad \mathrm{Fe}^{2+} / \mathrm{g}\right)\end{array}$ \\
\hline GPWL & - & $0.55 \pm 0.02^{\mathrm{a}}$ & $19.38 \pm 0.12^{\mathrm{a}}$ & $3.61 \pm 0.09^{\mathrm{a}}$ & $186.41 \pm 0.62^{\mathrm{a}}$ & $129.18 \pm 0.72^{\mathrm{a}}$ \\
\hline GPWM & $90.3 \pm 0.01$ & $0.40 \pm 0.01^{b}$ & $18.05 \pm 0.10^{\mathrm{b}}$ & $3.30 \pm 0.07^{b}$ & $134.45 \pm 0.42^{b}$ & $76.76 \pm 0.26^{\mathrm{b}}$ \\
\hline $\begin{array}{l}\text { he experiments } \\
\text { omace wine mic } \\
\text { ontent; ABTS = } \\
\text { quivalent antiox }\end{array}$ & $\begin{array}{l}\text { performed in tril } \\
\text {-apsulated; } \mathrm{a}_{\mathrm{w}}=\mathrm{w} \\
\text {-azino-bis (3-eth } \\
\text { capacity. Values }\end{array}$ & $\begin{array}{l}\text { and the resul } \\
\text { activity; TPC = } \\
\text { nzothiazoline- } 6 \\
\text { owed by differe }\end{array}$ & prenoric coin & $=$ Ferric redu & ace wine lyophiliz & $\begin{array}{l}\text {; GPWM }=\text { Grape } \\
\text { Total anthocyanin } \\
\text { TEAC }=\text { Trolox- } \\
\text { ence }(p<0.05) \text { by }\end{array}$ \\
\hline
\end{tabular}

\subsection{Total Phenolic Compounds (TPC), Total Anthocyanin Content (TAC) and antioxidant activity of GPWL and GPWM}

The content of phenolic compounds obtained for GPWL and GPWM was $19.38 \pm 0.12$ and $18.05 \pm 0.10 \mathrm{mg}$ GAE/g, respectively (Table 1). However, González-Centeno et al. (2015) reported lower TPC content (7.71 mg GAE/g) in ethanolic extracts of Vitis vinifera co-products. While that, Melo et al. (2011) found $16.57 \mathrm{mg} \mathrm{GAE} / \mathrm{g}$ in the ethanolic extract of grape pomace (Vitis labrusca L.). Several authors have suggested that the differences could arise from variations in raw material, extraction techniques and solvent type, as well as environmental factors, agronomic practices, and even vinification processes (Casagrande et al., 2019; Beres et al., 2017; Çam et al., 2014).

The total anthocyanin content found in GPWL and GPWM was $3.61 \pm 0.09$ and $3.30 \pm 0.07 \mathrm{mg}$ cyanidin3 -glucoside/g, respectively. These results were higher than those reported by Xu et al. (2015) in grape pomace from two Virginia-grown Vitis vinifera varieties. The authors found $1.38 \pm 0.03 \mathrm{mg}$ cyanidin-3glucoside/g for Cabernet Franc and $0.02 \pm 0.01 \mathrm{mg}$ cyanidin-3-glucoside/g for Viognier varieties. The difference between the values found can be due to grape variety, extraction process condition, year and location of farming, among other variables that can directly influence the results.

The results of the antioxidant activity of GPWL and GPWM assessed by ferric reducing antioxidant power and ABTS radical scavenging methods are summarized in Table 1 . The antioxidant activity by ABTS radical scavenging method for GPWL and GPWM was $186.41 \pm 0.62$ and $134.45 \pm 0.42 \mu \mathrm{mol} \mathrm{TEAC/g}$, respectively. These results were lower than the values founded by some authors that studied grape pomace dried in a spray dryer (Souza et al., 2014; Jara-Palacios et al., 2014). Concerning the values obtained for FRAP assay, they were lower than those reported by Rockenbach et al. (2011), who found $249.46 \mu \mathrm{mol}$ of $\mathrm{Fe}^{2+} / \mathrm{g}$ in pomace of Vitis vinifera $\mathrm{L}$. grape variety.

On the basis of the findings, the microencapsulation favored a reduction in bioactive compounds content with antioxidant activity when compared to lyophilized extracts (Table 1). In fact, according to Ballesteros et al. (2017), the drying process showed to be important in the efficacy of encapsulation, being freeze-drying an excellent technique for the maintenance of phenolic compounds. The compounds degradation depends on the analyzed matrix and the processing conditions (Borrmann et al., 2013). In addition, the variation of antioxidant activity for encapsulated extracts can be related to different 
interactions between the sample and the carrier agent, responding in different ways and often increasing or decreasing their activity (Carneiro et al., 2013). Thus, it becomes difficult to correlate the antioxidant activity and $\mathrm{ME}$, in response to various interactions that the agent may have with the sample. However, according to several authors (Sensoy et al., 2006; Mrkìc et al., 2006), oxidation reactions can occur during drying, and polyphenolic compounds found in an intermediate oxidation state may exhibit a greater scavenging activity of free radicals than those non-oxidized polyphenols.

\subsection{Phenolic compound profile}

The TPC analysis in GPWL and GPWM extracts by the Folin-Ciocalteu method do not give a full understanding of the qualification or quantification of the phenolic constituents. Therefore, it was necessary to analyze HPLC-DAD in the grape pomace extracts and the results are summarized in Table 2.

Six different phenolic compounds, gallic acid, vanillic acid, cafeic acid, coumaric acid, ferulic acid, and trans-resveratrol were found using HPLC, though their concentrations differed significantly. Gallic acid was the most abundant phenolic compound found in the GPWL and GPWM, while the caffeic acid was the least abundant phenolic compound in these extracts. However, the coumaric acid was found only in the GPWL.

Another important compound found in both GPWL and GPWM was the trans-resveratrol, which was detected in a high concentration of $7.84 \pm 0.23$ and $6.09 \pm 0.02 \mathrm{mg} / 100 \mathrm{~g}$, respectively, making them nutritionally interesting. The results differ from levels found by Sagdic et al. (2011), which reported trans-resveratrol values of 12.2 and $14.6 \mu \mathrm{g} / \mathrm{g}$ in two grape pomace varieties from Turkey (Gamay \& Kalecick karasi). In fact, phenolic acids and trans-resveratrol have been shown to exhibit antioxidant (Casagrande et al., 2019; Jara-Palacios et al., 2014; Ruberto et al., 2007), anticancer (Zhang et al., 2015), anti-inflammatory (Charradi et al., 2018), cardioprotective (Wu \& Hsieh, 2011) and neuroprotective (Bastianetto et al., 2015) properties as well as antimicrobial activity against several microorganisms (Xu et al., 2015; Sagdic et al., 2011).

The levels of all phenolic compounds found in the GPWL extract were higher than for GPWM extract, and this difference was statistically significant $(p<0.05)$ (Table 2$)$. These losses can be due to exposure to high temperatures and oxygen, which can make the materials more susceptible to degradation reactions (Kuck \& Noreña 2016). However, according to Farrag et al. (2018), the bioactive compounds of material microencapsulated by spray dryer has the ability to be released from the capsules in a controlled way and under specific conditions, besides presenting better solubility and mixing facility in the food matrix.

Table 2. Phenolic compounds profile by HPLC of GPWL and GPWM.

\begin{tabular}{ccccccc}
\hline $\begin{array}{c}\text { Phenolic compound } \\
(\mathbf{m g} / \mathbf{1 0 0} \mathbf{g})\end{array}$ & Gallic acid & Vanillic acid & Caffeic acid & $\begin{array}{c}\text { Coumaric } \\
\text { acid }\end{array}$ & Ferulic acid & $\begin{array}{c}\text { Trans- } \\
\text { resveratrol }\end{array}$ \\
\hline Retention time $(\mathrm{min})$ & 8.60 & 24.30 & 24.60 & 28.70 & 29.50 & 32.80 \\
\hline$K(\mathrm{~nm})$ & 272 & 260 & 323 & 309 & 322 & 308 \\
\hline \multirow{2}{*}{ Regression equation } & $\mathrm{y}=0.313 \mathrm{x}-$ & $\mathrm{y}=0.263 \mathrm{x}+$ & $\mathrm{y}=0.691 \mathrm{x}-$ & $\mathrm{y}=0.540 \mathrm{x}-$ & $\mathrm{y}=0.657 \mathrm{x}+$ & $\mathrm{y}=0.702 \mathrm{x}+$ \\
\hline $\mathrm{R}^{2}$ & 0.017 & 0.023 & 0.001 & 0.360 & 0.007 & 0.018 \\
\hline $\mathrm{LOD}(\mathrm{mg} / \mathrm{mL})$ & 0.996 & 0.998 & 0.997 & 0.999 & 0.999 & 0.817 \\
\hline $\mathrm{LOQ}(\mathrm{mg} / \mathrm{mL})$ & 0.10 & 0.08 & 0.03 & 0.02 & 0.10 & 0.05 \\
\hline GPWL & 0.34 & 2.72 & 0.11 & 0.08 & 0.36 & 0.16 \\
\hline GPWM & $7.59 \pm 0.21^{\mathrm{a}}$ & $2.04 \pm 0.31^{\mathrm{a}}$ & $0.41 \pm 0.01^{\mathrm{a}}$ & $2.45 \pm 0.18^{\mathrm{a}}$ & $2.99 \pm 0.14^{\mathrm{a}}$ & $7.84 \pm 0.23^{\mathrm{a}}$ \\
\hline
\end{tabular}

The experiment was performed in triplicate and the results expressed as means. $\mathrm{R}^{2}=$ correlation coefficient; $\mathrm{LOD}=$ Limit of detection; LOQ = Limit of quantification. Values followed by different small letters in the same column indicate a significant difference $(p<0.05)$ by Tukey's test; GPWL $=$ Grape pomace wine lyophilized; GPWM $=$ Grape pomace wine microencapsulated. $>$ LD $=$ Less Than Limit of Detection. 


\subsection{Effect of grape pomace on oxidative stability in chicken pâté}

The addition of natural product extracts in food is an alternative that extends the shelf life, increase safety and prevent damage caused by lipid oxidation (Carneiro et al., 2013; Karre et al., 2013). Thus, the TBARS test was used as an indicator of the degree of lipid oxidation in chicken pâté which GPWL and GPWM were added to inhibit this process. The TBARS average values increased over time and ranged from $1.42 \pm 0.04$ to $2.89 \pm 0.09 \mathrm{mg}$ malonaldehyde/ $\mathrm{kg}$ pâté at the end of the experiment (42 days) (Table 3). TBARS values for the control treatment (T1, no added antioxidant) ranged from $2.01 \pm 0.04$ to $3.62 \pm 0.06 \mathrm{mg}$ malonaldehyde/kg pâté, while, the chicken pâté prepared with sodium erythorbate had TBARS values that ranged from $1.84 \pm 0.04$ to $3.00 \pm 0.10 \mathrm{mg}$ malonaldehyde $/ \mathrm{kg}$ pâté. In fact, according to Pateiro et al. (2015) and Sampaio et al. (2012), the oxidative reactions of the meat begin during the processing of ingredients and before the addition of antioxidants.

Table 3. Average values of TBARS in chicken pâté during storage at $4{ }^{\circ} \mathrm{C}$.

\begin{tabular}{|c|c|c|c|c|c|c|c|}
\hline \multirow{3}{*}{ Treatments } & \multicolumn{7}{|c|}{ TBARS (mg of malonaldehyde/kg of pâté) } \\
\hline & \multicolumn{7}{|c|}{ Storage time (days) } \\
\hline & $\mathbf{0}$ & 7 & 14 & 21 & 28 & 35 & 42 \\
\hline $\mathrm{T} 1$ & $2.01 \pm 0.04^{\mathrm{a}, \mathrm{F}}$ & $2.14 \pm 0.06^{\mathrm{a}, \mathrm{E}}$ & $2.20 \pm 0.01^{\mathrm{a}, \mathrm{D}}$ & $2.25 \pm 0.02^{\mathrm{a}, \mathrm{C}}$ & $2.37 \pm 0.08^{\mathrm{a}, \mathrm{B}}$ & $2.38 \pm 0.05^{\mathrm{a}, \mathrm{B}}$ & $3.62 \pm 0.06^{\mathrm{a}, \mathrm{A}}$ \\
\hline $\mathrm{T} 2$ & $1.84 \pm 0.04^{\mathrm{b}, \mathrm{E}}$ & $1.81 \pm 0.03^{\mathrm{b}, \mathrm{E}}$ & $1.74 \pm 0.03^{\mathrm{b}, \mathrm{F}}$ & $1.86 \pm 0.01^{\mathrm{c}, \mathrm{D}}$ & $2.10 \pm 0.02^{\mathrm{b}, \mathrm{C}}$ & $2.37 \pm 0.02^{\mathrm{a}, \mathrm{B}}$ & $3.00 \pm 0.10^{\mathrm{b}, \mathrm{A}}$ \\
\hline $\mathrm{T} 3$ & $0.86 \pm 0.01^{\mathrm{d}, \mathrm{F}}$ & $1.51 \pm 0.03^{\mathrm{d}, \mathrm{E}}$ & $1.55 \pm 0.04^{\mathrm{d}, \mathrm{E}}$ & $1.73 \pm 0.02^{\mathrm{d}, \mathrm{D}}$ & $2.05 \pm 0.04^{\mathrm{c}, \mathrm{C}}$ & $2.31 \pm 0.04^{\mathrm{b}, \mathrm{B}}$ & $2.46 \pm 0.08^{\mathrm{d}, \mathrm{A}}$ \\
\hline $\mathrm{T} 4$ & $0.96 \pm 0.03^{\mathrm{c}, \mathrm{F}}$ & $1.70 \pm 0.02^{\mathrm{c}, \mathrm{E}}$ & $1.71 \pm 0.05^{\mathrm{c}, \mathrm{E}}$ & $1.90 \pm 0.03^{\mathrm{b}, \mathrm{D}}$ & $2.06 \pm 0.04^{\mathrm{c}, \mathrm{C}}$ & $2.18 \pm 0.03^{\mathrm{c}, \mathrm{B}}$ & $2.50 \pm 0.04^{\mathrm{c}, \mathrm{A}}$ \\
\hline Average & $1.42 \pm 0.04^{\mathrm{F}}$ & $1.79 \pm 0.03^{\mathrm{E}}$ & $1.80 \pm 0.03^{\mathrm{E}}$ & $1.94 \pm 0.04^{\mathrm{D}}$ & $2.14 \pm 0.06^{\mathrm{C}}$ & $2.32 \pm 0.06^{\mathrm{B}}$ & $2.89 \pm 0.09^{\mathrm{A}}$ \\
\hline
\end{tabular}

The control treatment (T1, no added antioxidant) had significantly higher TBARS values $(p<0.05)$ when compared to other treatments with antioxidants (T2, T3, and T4) in all periods of storage.

Several authors (Anjos et al., 2019; Almeida et al., 2017; Selani et al., 2011) refer that values lower than $3 \mathrm{mg}$ of malonaldehyde/ $\mathrm{kg}$ of meat product can be considered suitable and safe for consumption. According to these findings, all the chicken pâté prepared with GPWL and GPWM could be considered in good condition during all storage periods (values lower $2.50 \mathrm{mg}$ malonaldehyde/kg chicken pâté).

During the whole storage, the TBARS values of chicken pâté treated with GPWL (T3) were always significantly lower than other chicken pâté containing GPWM (T4). However, the pâté prepared with both grape pomace as a natural antioxidant (GPWL and GPWM) had TBARS values lower than the pâté prepared with the commercial antioxidant throughout the storage period.

At the 42 days of storage, chicken pâté treated with GPWL and GPWM inhibited more than $30 \%$ of lipid oxidation in comparison to control pâté. Regarding GPWM, the positive effect can be probably due to the gradual release of the bioactive compounds from GPWM in chicken pâté. Moreover, the results indicated that grape pomace from winemaking could decrease the TBARS values in chicken pâté effectively compared to other treatments throughout storage. Its reduction in lipid oxidation of chicken pâté would be due to the antioxidant activity of the phenolic compounds present in the grape pomace mainly trans-resveratrol and gallic acid. In addition, according to Doshi et al. (2015), the antioxidant properties of the grape pomace can be ascribed to the synergism of global phenolics composition and other substances present in the extracts. Several studies have reported that the agro-industrial extracts are an excellent source of natural antioxidants and can increase the meat shelf life due to inhibition of lipid oxidation (Almeida et al., 2017; Reis et al., 2017). 


\section{Conclusion}

In this study, the GPWM extract was efficient (90\%), and produced a food ingredient with low water activity and excellent antioxidant activity, suitable for storage and consumption. However, the GPWL was a little more effective in the lipid oxidation inhibition in chicken pâte than GWPM. The grape pomace extracts in chicken pate could effectively inhibited the lipid oxidation during refrigerated storage owing to its high phenolic content. Gallic acid, caffeic acid, vanillic acid, ferulic acid, coumaric acid, and trans-resveratrol were in a higher concentration in the GWPL than GWPM. The use of natural antioxidants as grape pomace from winemaking (GPWL and GPWM) can improve the shelf life of chicken pâté. Additionally, both had TBARS values lower than the pâté prepared with the commercial antioxidant throughout the storage period. Although additional information such as antimicrobial activity, food safety, and physicochemical and sensory properties is still required, the effectiveness of winery by-products to reduce lipid oxidation in chicken pâté already makes them particularly attractive for the meat industry.

\section{Acknowledgements}

The authors thank the National Council for Scientific and Technological Development - CNPq and the Araucaria Research Foundation for the financial support and Analysis Center at UTFPR - Pato Branco/PR.

\section{References}

Almeida, J. F., Reis, A. S., Heldt, L. F. S., Pereira, D., Bianchin, M., Moura, C., Plata-Oviedo, M. V., Haminiuk, C. W. I., Ribeiro, I. S., Luz, C. F. P., \& Carpes, S. T. (2017). Lyophilized bee pollen extract: A natural antioxidant source to prevent lipid oxidation in refrigerated sausages. Lebensmittel-Wissenschaft + Technologie, 76, 299-305. http://dx.doi.org/10.1016/j.lwt.2016.06.017

Anjos, O., Fernandes, R., Cardoso, S. M., Delgado, T., Farinha, N., Paula, V., Estevinho, L. M., \& Carpes, S. T. (2019). Bee pollen as a natural antioxidant source to prevent lipid oxidation in black pudding. Lebensmittel-Wissenschaft + Technologie, 111, 869-875. http://dx.doi.org/10.1016/j.Iwt.2019.05.105

Arnao, M. B., Cano, A., \& Acosta, M. (2001). The hydrophilic and lipophilic contribution to total antioxidant activity. Food Chemistry, 73(2), 239-244. http://dx.doi.org/10.1016/S0308-8146(00)00324-1

Bajaj, P. R., Tang, J., \& Sablani, S. S. (2015). Pea protein isolates: Novel wall materials for microencapsulating flaxseed oil. Food and Bioprocess Technology, 8(12), 2418-2428. http://dx.doi.org/10.1007/s11947-015-1589-6

Ballesteros, L. F., Ramirez, M. J., Orrego, C. E., Teixeira, J. A., \& Mussatto, S. I. (2017). Encapsulation of antioxidant phenolic compounds extracted from spent coffee grounds by freeze-drying and spray-drying using different coating materials. Food Chemistry, 237, 623-631. PMid:28764044. http://dx.doi.org/10.1016/j.foodchem.2017.05.142

Bastianetto, S., Ménard, C., \& Quirion, R. (2015). Neuroprotective action of resveratrol. Biochimica et Biophysica Acta, 1852(6), 1195-1201. PMid:25281824. http://dx.doi.org/10.1016/j.bbadis.2014.09.011

Beres, C., Costa, G. N. S., Cabezudo, I., Silva-James, N. K., Teles, A. S. C., Cruz, A. P. G., Mellinger-Silva, C., Tonon, R. V., Cabral, L. M. C., \& Freitas, S. P. (2017). Towards integral utilization of grape pomace from winemaking process: A review. Waste Management, 68, 581-594. PMid:28734610. http://dx.doi.org/10.1016/j.wasman.2017.07.017

Borrmann, D., Pierucci, A. P. T. R., Leite, S. G. F., \& Leão, M. H. M. R. (2013). Microencapsulation of passion fruit (Passiflora) juice with noctenylsuccinate derivatised starch using spray drying. Food and Bioproducts Processing, 91(1), 23-27. http://dx.doi.org/10.1016/j.fbp.2012.08.001

Çam, M., Içyer, N. C., \& Erdogan, F. (2014). Pomegranate peel phenolics: Microencapsulation, storage stability and potential ingredient for functional food development. Lebensmittel-Wissenschaft + Technologie, 55(1), 117-123. http://dx.doi.org/10.1016/j.Iwt.2013.09.011

Carneiro, H. C. F., Tonon, R. V., Grosso, C. R. F., \& Hubinger, M. D. (2013). Encapsulation efficiency and oxidative stability of flaxseed oil microencapsulated by spray drying using different combinations of wall materials. Journal of Food Engineering, 115(4), 443-451. http://dx.doi.org/10.1016/j.jfoodeng.2012.03.033

Casagrande, M., Zanela, J., Pereira, D., Lima, V. A., Oldoni, T. L. C., \& Carpes, S. T. (2019). Optimization of the xtraction of antioxidant phenolic compounds from grape pomace using response surface methodology. Journal of Food Measurement and Characterization, 13(2), 1120-1129. http://dx.doi.org/10.1007/s11694-018-00027-x

Charradi, K., Mahmoudi, M., Bedhiafi, T., Jebari, K., El May, M. V., Limam, F., \& Aouani, E. (2018). Safety evaluation, antioxidative and anti-inflammatory effects of subchronically dietary supplemented high dosing grape seed powder (GSP) to healthy rat. Biomedicine and Pharmacotherapy, 107, 534-546. PMid:30114637. http://dx.doi.org/10.1016/j.biopha.2018.08.031

Doshi, P., Adsule, P., Banerjee, K., \& Oulkar, D. (2015). Phenolic compounds, antioxidant activity and insulinotropic effect of extracts prepared from grape (Vitis vinifera L) byproducts. Journal of Food Science and Technology, 52(1), 181-190. PMid:25593367. http://dx.doi.org/10.1007/s13197-013-0991-1 
Falowo, A. B., Fayemi, P. O., \& Muchenje, V. (2014). Natural antioxidants against lipid - protein oxidative deterioration in meat and meat products : A review. Food Research International, 64, 171-181. PMid:30011637.

http://dx.doi.org/10.1016/j.foodres.2014.06.022

Farrag, A., El-Messery, T. M., El-Said, M. M., Soliman, T. N., \& El-Din, H. M. F. (2018). Microencapsulation of grape phenolic compounds using whey proteins as a carrier vehicle. The Journal of Biological Sciences, 18(7), 373-380.

http://dx.doi.org/10.3923/jbs.2018.373.380

Favaro-Trindade, C. S., Pinho, S. C., \& Rocha, G. A. (2008). Review: Microencapsulation of food ingredients. Brazilian Journal of Food Technology, 11, 103-112.

Fernandes, R. V. B., Marques, G. R., Borges, S. V., \& Botrel, D. A. (2014). Effect of solids content and oil load on the microencapsulation process of rosemary essential oil. Industrial Crops and Products, 58, 173-181. http://dx.doi.org/10.1016/j.indcrop.2014.04.025

González-Centeno, M. R., Comas-Serra, F., Femenia, A., Rosselló, C., \& Simal, S. (2015). Effect of power ultrasound application on aqueous extraction of phenolic compounds and antioxidant capacity from grape pomace (Vitis vinifera L.): Experimental kinetics and modeling. Ultrasonics Sonochemistry, 22, 506-514. PMid:24970116. http://dx.doi.org/10.1016/j.ultsonch.2014.05.027

He, X., \& Hwang, H. M. (2016). Nanotechnology in food science: Functionality, applicability, and safety assessment. Journal of Food and Drug Analysis, 24(4), 671-681. PMid:28911604. http://dx.doi.org/10.1016/j.jfda.2016.06.001

Jara-Palacios, M. J., Hernanz, D., Escudero-Gilete, M. L., \& Heredia, F. J. (2014). Antioxidant potential of white grape pomaces: Phenolic composition and antioxidant capacity measured by spectrophotometric and cyclic voltammetry methods. Food Research International, 66, 150-157. http://dx.doi.org/10.1016/j.foodres.2014.09.009

Jyothi, N. V. N. P., Prasanna, P. M., Sakarkar, S. N., Prabha, K. S., Ramaiah, P. S., \& Srawan, G. Y. (2010).

Microencapsulation techniques, factors influencing encapsulation efficiency. Journal of Microencapsulation, 27(3), 187-197. PMid:20406093. http://dx.doi.org/10.3109/02652040903131301

Karre, L., Lopez, K., \& Getty, K. J. K. (2013). Natural antioxidants in meat and poultry products. Meat Science, 94(2), 220-227. PMid:23501254. http://dx.doi.org/10.1016/j.meatsci.2013.01.007

Kim, S. J., Min, S. C., Shin, H. J., Lee, Y. J., Cho, A. R., Kim, S. Y., \& Han, J. (2013). Evaluation of the antioxidant activities and nutritional properties of ten edible plant extracts and their application to fresh ground beef. Meat Science, 93(3), 715-722. PMid:23273483. http://dx.doi.org/10.1016/j.meatsci.2012.11.029

Kuck, L. S., \& Noreña, C. P. Z. (2016). Microencapsulation of grape (Vitis labrusca var. Bordo) skin phenolic extract using gum arabic, polydextrose, and partially hydrolyzed guar gum as encapsulating agents. Food Chemistry, 194, 569-576.

PMid:26471594. http://dx.doi.org/10.1016/j.foodchem.2015.08.066

Kukic, J., Popovic, V., Petrovic, S., Mucaji, P., Ciric, A., Stojkovic, D., \& Sokovic, M. (2008). Antioxidant and antimicrobial activity of Cynara cardunculus extracts. Food Chemistry, 107(2), 861-868. http://dx.doi.org/10.1016/j.foodchem.2007.09.005

Lee, J., Durst, R. W. R., \& Wrolstad, E. (2005). Determination of total monomeric anthocyanin pigment content of fruit juices, beverages, natural colorants, and wines by the $\mathrm{pH}$ differential method: Collaborative study. Journal of AOAC International, 88(5), 1269-1278. PMid:16385975. http://dx.doi.org/10.1093/jaoac/88.5.1269

Madene, A., Jacquot, M., Scher, J., \& Desobry, S. (2006). Flavour encapsulation and controlled release: A review. International Journal of Food Science \& Technology, 41(1), 1-21. http://dx.doi.org/10.1111/j.1365-2621.2005.00980.x

Melo, P. S., Bergamaschi, K. B., Tiveron, A. P., Massarioli, A. P., Oldoni, T. L. C., Zanus, M. C., Pereira, G. E., \& Alencar, S. M. (2011). Phenolic composition and antioxidant activity of agro-industrial wastes. Ciência Rural, 41, 1088-1093.

http://dx.doi.org/10.1590/S0103-84782011000600027

Mrkic, V., Cocci, E., Rosa, M. D., \& Sacchetti, G. (2006). Effect of drying conditions on bioactive compounds and antioxidant activity of broccoli (Brassica oleracea L.). Journal of the Science of Food and Agriculture, 86(10), 1559-1566.

http://dx.doi.org/10.1002/jsfa.2554

Nori, M. P., Favaro-Trindade, C. S., Matias de Alencar, S., Thomazini, M., de Camargo Balieiro, J. C., \& Contreras Castillo, C. J. (2011). Microencapsulation of propolis extract by complex coacervation. Lebensmittel-Wissenschaft + Technologie, 44(2), 429435. http://dx.doi.org/10.1016/j.Iwt.2010.09.010

Pateiro, M., Lorenzo, J., Vázquez, J., \& Franco, D. (2015). Oxidation stability of pig liver pâté with increasing levels of natural antioxidants (grape and tea). Antioxidants, 4(1), 102-123. PMid:26785340. http://dx.doi.org/10.3390/antiox4010102

Peixoto, C. M., Dias, M. I., Alves, M. J., Calhelha, R. C., Barros, L., Pinho, S. P., \& Ferreira, I. C. F. R. (2018). Grape pomace as a source of phenolic compounds and diverse bioactive properties. Food Chemistry, 253, 132-138. PMid:29502813. http://dx.doi.org/10.1016/j.foodchem.2018.01.163

Re, R., Pellegrini, N., Proteggente, A., Pannala, A., Yang, M., \& Rice-Evans, C. (1999). Antioxidant activity applying an improved ABTS ${ }^{+}$radical cation decolorization assay. Free Radical Biology \& Medicine, 26(9-10), 1231-1237. PMid:10381194. http://dx.doi.org/10.1016/S0891-5849(98)00315-3

Reis, A. S., Diedrich, C., Moura, C., Pereira, D., Almeida, J. F., Silva, L. D., Plata Oviedo, M. S. V., Tavares, R. A. W., \& Carpes, S. T. (2017). Physico-chemical characteristics of microencapsulated propolis co-product extract and its effect on storage stability of burger meat during storage at -15 C. Lebensmittel-Wissenschaft + Technologie, 76, 306-313.

http://dx.doi.org/10.1016/j.lwt.2016.05.033

Rockenbach, I. I., Rodrigues, E., Gonzaga, L. V., Caliari, V., Genovese, M. I., Gonçalves, A. E. S. S., \& Fett, R. (2011). Phenolic compounds content and antioxidant activity in pomace from selected red grapes (Vitis vinifera L. and Vitis labrusca L.) widely produced in Brazil. Food Chemistry, 127(1), 174-179. http://dx.doi.org/10.1016/j.foodchem.2010.12.137 
Ruberto, G., Renda, A., Daquino, C., Amico, V., Spatafora, C., Tringali, C., \& Tommasi, N. D. (2007). Polyphenol constituents and antioxidant activity of grape pomace extracts from five Sicilian red grape cultivars. Food Chemistry, 100(1), 203-211. http://dx.doi.org/10.1016/j.foodchem.2005.09.041

Sagdic, O., Ozturk, I., Ozkan, G., Yetim, H., Ekici, L., \& Yilmaz, M. T. (2011). RP-HPLC-DAD analysis of phenolic compounds in pomace extracts from five grape cultivars: Evaluation of their antioxidant, antiradical and antifungal activities in orange and apple juices. Food Chemistry, 126(4), 1749-1758. PMid:25213954. http://dx.doi.org/10.1016/j.foodchem.2010.12.075

Sampaio, G. R., Saldanha, T., Soares, R. A. M., \& Torres, E. A. F. S. (2012). Effect of natural antioxidant combinations on lipid oxidation in cooked chicken meat during refrigerated storage. Food Chemistry, 135(3), 1383-1390. PMid:22953870. http://dx.doi.org/10.1016/j.foodchem.2012.05.103

Selani, M. M., Contreras-Castillo, C. J., Shirahigue, L. D., Gallo, C. R., Plata-Oviedo, M., \& Montes-Villanueva, N. D. (2011). Wine industry residues extracts as natural antioxidants in raw and cooked chicken meat during frozen storage. Meat Science, 88(3), 397-403. PMid:21342750. http://dx.doi.org/10.1016/j.meatsci.2011.01.017

Sensoy, I., Rosen, R. T., Ho, C. T., \& Karwe, M. V. (2006). Effect of processing on buckwheat phenolics and antioxidant activity. Food Chemistry, 99(2), 388-393. http://dx.doi.org/10.1016/j.foodchem.2005.08.007

Shahidi, F., \& Zhong, Y. (2010). Novel antioxidants in food quality preservation and health promotion. European Journal of Lipid Science and Technology, 12(9), 930-940. http://dx.doi.org/10.1002/ejlt.201000044

Singleton, V. L., Orthofer, R., \& Lamuela-Raventós, R. M. (1999). Analysis of total phenols and other oxidation substrates and antioxidants by means of Folin-Ciocalteau reagent. Methods in Enzymology, 299, 152-178. http://dx.doi.org/10.1016/S00766879(99)99017-1

Soares, S., Kohl, S., Thalmann, S., Mateus, N., Meyerhof, W., \& De Freitas, V. (2013). Different phenolic compounds activate distinct human bitter taste receptors. Journal of the Science of Food and Agriculture, 61(7), 1525-1533. PMid:23311874. http://dx.doi.org/10.1021/jf304198k

Souza, V. B. D., Fujita, A., Thomazini, M., Da Silva, E. R., Lucon Junior, J. F., Genovese, M. I., \& Favaro-Trindade, C. S. (2014). Functional properties and stability of spray-dried pigments from Bordo grape (Vitis labrusca L.) winemaking pomace. Food Chemistry, 164, 380-386. PMid:24996348. http://dx.doi.org/10.1016/j.foodchem.2014.05.049

Tonon, R. V., Brabet, C., \& Hubinger, M. D. (2010). Anthocyanin stability and antioxidant activity of spray-dried açai (Euterpe oleracea Mart.) juice produced with different carrier agents. Food Research International, 43(3), 907-914. http://dx.doi.org/10.1016/j.foodres.2009.12.013

Wu, J. M., \& Hsieh, T.-C. (2011). Resveratrol: A cardioprotective substance. Annals of the New York Academy of Sciences, 1215(1), 16-21. PMid:21261637. http://dx.doi.org/10.1111/j.1749-6632.2010.05854.x

Xu, Y., Burton, S., Kim, C., \& Sismour, E. (2015). Phenolic compounds, antioxidant, and antibacterial properties of pomace extracts from four Virginia-grown grape varieties. Food Science \& Nutrition, 4(1), 125-133. PMid:26788319. http://dx.doi.org/10.1002/fsn3.264

Zhang, Y.-J., Gan, R.-Y., Li, S., Zhou, Y., Li, A.-N., Xu, D.-P., \& Li, H.-B. (2015). Antioxidant phytochemicals for the prevention and treatment of chronic diseases. Molecules, 20(12), 21138-21156. PMid:26633317.

http://dx.doi.org/10.3390/molecules201219753

Funding: National Council for Scientific and Technological Development - CNPq and the Araucaria Research Foundation and Analysis Center at UTFPR-Pato Branco/PR. 